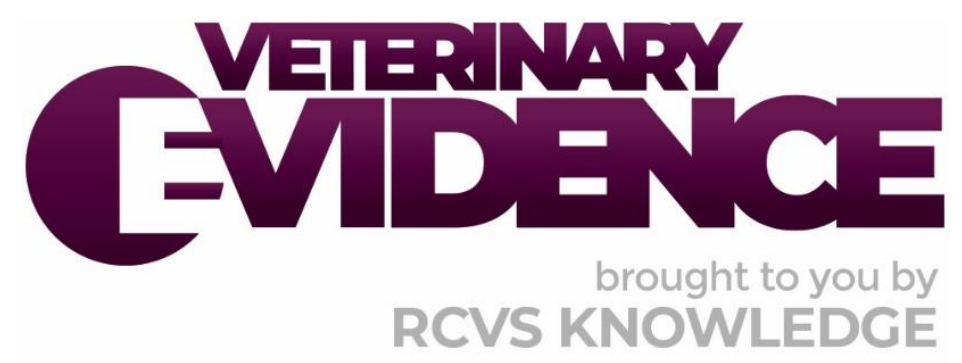

\title{
Is an Anchoring or Pocket Technique Best for Surgical Repair of Cherry Eye in Dogs?
}

A Knowledge Summary by

Jim Connah BVSc MANZCVS ${ }^{1}$

\footnotetext{
${ }^{1}$ Tasmanian Animal Hospitals, 29-31 Clarence St, Bellerive TAS 7018 Australia

* Corresponding Author (jimconnah@bigpond.com)
}

ISSN: 2396-9776

Published: 12 Feb 2019

in: Vol 4, Issue 1

DOI: http://dx.doi.org/10.18849/ve.v4i1.182

Reviewed by: Victoria Arbona (DVM, MS) and Kazuya Oikawa (DVM) 


\section{PICO question}

In dogs undergoing surgery for repair of a prolapsed gland of the third eyelid (cherry eye), is a pocket technique superior to an anchoring technique in preventing recurrence?

\section{Clinical bottom line}

For surgical treatment of a prolapsed gland of the third eyelid (cherry eye), there is currently no evidence to suggest that either an anchoring technique or a pocket technique is significantly better than the other when comparing recurrence rates. In practice, and until randomised controlled trials are carried out, veterinary surgeon preference and previous experience would be the relevant factors in choosing which operation to perform.

\section{Clinical Scenario}

You are presented with a 1-year-old Beagle with a unilateral cherry eye. It has been present for two months and is not bothering the dog. The owner wants to know what to do. You ring the two veterinary ophthalmologists in the local area for advice. One routinely performs an anchoring technique, whilst the other has had good results with a mucosal pocket technique. Having only two expert opinions to go by, you decide to look for any available higher level evidence.

\section{The evidence}

There is no evidence to suggest that one technique is superior to another. Whilst all the cited studies compared techniques, and reported excellent outcomes for both, only one (Multari et al., 2016) conducted any statistical analysis. This latter article did not show any significant difference in rates of recurrence. It was limited, however, by comparing a pocket technique with a pocket plus anchor technique.

\section{Summary of the evidence}

\begin{tabular}{|c|c|}
\hline \multicolumn{2}{|l|}{ Morgan, Duddy \& McClurg (1993) } \\
\hline Population: & $\begin{array}{l}\text { Case records of dogs presented with either unilateral or bilateral } \\
\text { cherry eye. }\end{array}$ \\
\hline Sample size: & 125 eyes in 89 dogs. \\
\hline Intervention details: & $\begin{array}{l}\text { The medical records of dogs with a prolapsed gland of the third } \\
\text { eyelid between June } 1980 \text { to June } 1990 \text { were examined. } \\
\text { Four groups of dogs: Excision of the gland ( } 43 \text { eyes), Gross \& Blogg } \\
\text { tacking (anchoring) technique (Gross, 1983) ( } 59 \text { eyes), Morgan } \\
\text { pocket technique (18 eyes) and no treatment ( } 5 \text { eyes). } \\
\text { Follow up period: } 2-10 \text { years. }\end{array}$ \\
\hline Study design: & Retrospective cohort study. \\
\hline Outcome studied: & $\begin{array}{l}\text { 1. Development of keratoconjunctivitis sicca (KCS). } \\
\text { 2. Recurrence of prolapse (anchoring and pocket groups). }\end{array}$ \\
\hline
\end{tabular}




\begin{tabular}{|c|c|}
\hline $\begin{array}{l}\text { Main findings: } \\
\text { (relevant to PICO question) }\end{array}$ & $\begin{array}{l}\text { 1. High recurrence rate in anchoring group ( } 30 / 51) \text {, usually } \\
\text { within } 1-8 \text { weeks after the initial surgery (eight dogs were } \\
\text { lost to follow up). } \\
\text { 2. Only } 1 / 17 \text { prolapses recurred with the pocket technique } \\
\text { (one dog was lost to follow up). }\end{array}$ \\
\hline Limitations: & $\begin{array}{l}\text { 1. No statistical analysis provided, so no direct comparisons of } \\
\text { treatment efficacy could be made. } \\
\text { 2. No indication of how long the follow up period was for } \\
\text { determining recurrence in all dogs. } \\
\text { 3. Nine animals lost to follow up. } \\
\text { 4. Retrospective study, which is lower in evidence hierarchy. } \\
\text { 5. The anchoring technique used in this paper is outdated, no } \\
\text { longer recommended and therefore less relevant to the } \\
\text { PICO question. } \\
\text { 6. The Morgan technique was developed by the authors due to } \\
\text { the high failure rate of the Gross technique - the Discussion } \\
\text { notes that the Kaswan anchoring technique (Kaswan \& } \\
\text { Martin, 1985) was tried but the cosmetic results were } \\
\text { unacceptable (there was no recurrence). There is no record } \\
\text { of this in either the Methods or Results sections and indeed } \\
\text { if these dogs were reoperated on. }\end{array}$ \\
\hline \multicolumn{2}{|l|}{ Lin \& Lin (2003) } \\
\hline Population: & Dogs presented with either unilateral or bilateral cherry eye. \\
\hline Sample size: & Seven eyes in five dogs. \\
\hline Intervention details: & $\begin{array}{l}\text { Two groups of dogs: Morgan pocket technique (Morgan et al., 1993) } \\
\text { (6 eyes) and Kaswan anchoring technique (Kaswan \& Martin, 1985) } \\
\text { (1 eye). } \\
\text { Follow up period: } 6-12 \text { months. }\end{array}$ \\
\hline Study design: & Prospective non-randomised cohort study. \\
\hline Outcome studied: & $\begin{array}{l}\text { 1. Detection of KCS. } \\
\text { 2. Re-prolapse of the gland. }\end{array}$ \\
\hline $\begin{array}{l}\text { Main findings: } \\
\text { (relevant to PICO question) }\end{array}$ & $\begin{array}{l}\text { 1. During the follow up period, there were no cases of KCS or } \\
\text { recurrence of prolapse. } \\
\text { 2. Noted in discussion that the pocket technique was easier to } \\
\text { perform. }\end{array}$ \\
\hline Limitations: & $\begin{array}{l}\text { 1. Small sample size. } \\
\text { 2. No indication why different techniques were employed, and } \\
\text { under what criteria dogs were allocated to groups. }\end{array}$ \\
\hline \multicolumn{2}{|l|}{ Gupta et al., (2016) } \\
\hline Population: & Dogs presented with either unilateral or bilateral cherry eye. \\
\hline Sample size: & 16 eyes in 10 dogs. \\
\hline Intervention details: & $\begin{array}{l}\text { Three groups of dogs: removal of gland ( } 8 \text { eyes of five dogs), Kaswan } \\
\text { anchoring technique (Kaswan \& Martin, 1985) ( } 4 \text { eyes of three dogs) } \\
\text { or modified Morgan pocket technique (Morgan et al., 1993) ( } 4 \text { eyes } \\
\text { of three dogs). }\end{array}$ \\
\hline
\end{tabular}




\begin{tabular}{|c|c|}
\hline Study design: & Prospective non-randomised cohort study. \\
\hline Outcome studied: & $\begin{array}{l}\text { 1. Recurrence of prolapse. } \\
\text { 2. Detection of KCS in all techniques. }\end{array}$ \\
\hline $\begin{array}{l}\text { Main findings: } \\
\text { (relevant to PICO question) }\end{array}$ & $\begin{array}{l}\text { 1. No cases of recurrence with the anchoring technique, } \\
\text { although there was one case of persistent protrusion of the } \\
\text { third eyelid. } \\
\text { 2. No cases of recurrence with the pocket technique. }\end{array}$ \\
\hline Limitations: & $\begin{array}{l}\text { 1. No indication of how long the follow up period was. } \\
\text { 2. No indication why different techniques were employed, and } \\
\text { how dogs were allocated to groups. }\end{array}$ \\
\hline \multicolumn{2}{|l|}{ Multari et al., (2016) } \\
\hline Population: & $\begin{array}{l}\text { Case records of dogs presented with either unilateral or bilateral } \\
\text { cherry eye. }\end{array}$ \\
\hline Sample size: & 420 eyes in 353 dogs. \\
\hline Intervention details: & $\begin{array}{l}\text { The medical records of dogs undergoing surgical repair of a } \\
\text { prolapsed gland of the third eyelid between January } 2002 \text { and June } \\
2013 \text { were examined. } \\
\text { Two groups of dogs: Morgan pocket technique (Morgan et al., 1993) } \\
\text { ( } 234 \text { eyes) and Morgan pocket technique combined with a modified } \\
\text { Stanley and Kaswan anchoring technique (Stanley \& Kaswan, 1994) } \\
\text { (186 eyes). }\end{array}$ \\
\hline Study design: & Retrospective cohort study. \\
\hline Outcome studied: & Recurrence of prolapse. \\
\hline $\begin{array}{l}\text { Main findings: } \\
\text { (relevant to PICO question) }\end{array}$ & $\begin{array}{l}\text { 1. There were recurrences in } 12 / 234 \text { eyes with the Morgan } \\
\text { pocket technique and in } 9 / 186 \text { eyes with the combined } \\
\text { technique (no significant difference, } P=0.892 \text { ). } \\
\text { 2. Recurrences were generally } 1-2 \text { months postoperatively. } \\
\text { 3. The techniques were compared within some breeds, but } \\
\text { only statistical analysis was provided for the Cane Corso (no } \\
\text { significant difference, } P=0.66 \text { ). }\end{array}$ \\
\hline Limitations: & $\begin{array}{l}\text { 1. No comparison between a pocket technique group and an } \\
\text { anchoring alone technique group. } \\
\text { 2. No indication of times of follow up for any of the dogs. } \\
\text { 3. Retrospective study, which is lower in evidence hierarchy. } \\
\text { 4. The study was non-randomised: dogs had been selected for } \\
\text { the combined technique if the surgeon had thought the } \\
\text { pocket technique alone would fail (chronic cases, large } \\
\text { glands, and dogs with poor temperament). }\end{array}$ \\
\hline
\end{tabular}

\section{Appraisal, application and reflection}

There are many published studies which purport the efficacy of various individual surgical treatments for repair of prolapsed glands of the third eyelid (cherry eye). These were excluded from the search as they did not compare the efficacy of any new surgical approaches to older ones. White \& Brennan (2018) have 
recently reviewed the surgical techniques for the correction of prolapsed glands of the third eyelid. There was insufficient evidence to recommend one technique over another with regards to recurrence rates or development of KCS. A meta-analysis performed for studies reporting outcomes of the Morgan pocket and anchoring techniques, however, showed that there was a similar surgical failure rate $(2-3 \%)$ between the two techniques (White \& Brennan, 2018).

The Morgan pocket technique was developed by Morgan, Duddy \& McClurg (1993) because an outdated tacking technique resulted in too many treatment failures. There was no statistical analysis performed, but the former technique appeared to be more efficacious.

Whilst cohort studies generally appear higher in the hierarchy of evidence based veterinary medicine, the two included in this Knowledge Summary (Lin \& Lin, (2003); Gupta et al., (2016)) suffered from having no control groups. Another cohort study (Gökçe, 2001) which compared removal of the gland (8 eyes of five dogs), the Kaswan anchoring technique (4 eyes of three dogs) and the modified Morgan pocket technique (4 eyes of three dogs) was only available in English as an abstract. It noted, however, that there was a higher recurrence rate with the anchoring technique (no statistical analysis was available).

Only one study (Multari et al., (2016)) compared recurrences after two techniques with statistical analysis, but no significance was found $(P=0.892)$. Unfortunately, this study compared the Morgan pocket technique with a combined Morgan pocket and Stanley and Kaswan anchoring technique. This made the study less relevant to the PICO question.

There is clearly a need for randomised controlled studies to determine the answer to the PICO question. Large numbers of eyes need to be treated across multiple institutions with multiple veterinary surgeons. An especially useful group of dogs may be those which present with bilateral cherry eye: an anchoring procedure could be performed in one eye and a pocket in the other. Outcomes could then be compared in the same animal.

\section{Methodology Section}

\begin{tabular}{|c|c|}
\hline $\begin{array}{r}\text { Databases searched and dates } \\
\text { covered: }\end{array}$ & $\begin{array}{l}\text { 1. CAB Abstracts on Ovid platform } 1973 \text { to } 2018 \text { Week } 15 \\
\text { 2. Medline on Ovid platform } 1946 \text { to April Week 2, } 2018 \\
\text { 3. Web of Science Core Collection } 1900 \text {-present }\end{array}$ \\
\hline Search terms: & $\begin{array}{l}\text { CAB Abstracts and Medline: } \\
\text { (dog OR dog* OR canine OR canis OR exp dogs/) } \\
\text { AND } \\
\text { (surg* OR repair OR replacement) } \\
\text { AND } \\
\text { (cherry eye OR eyelid adj3 prolaps* OR third adj3 prolaps* OR } \\
\text { nictita* adj3 prolaps* OR gland adj4 prolaps* OR gland adj4 third OR } \\
\text { gland adj4 eyelid OR gland adj4 nictita*) } \\
\text { AND } \\
\text { (pocket techni* OR tacking OR anchor* techni* or mucosa* adj3 } \\
\text { pocket OR anchor* adj4 orbital OR anchor* adj4 rim OR imbricat*) } \\
\text { Web of Science: } \\
\text { (dog OR dog* OR canine OR canis) } \\
\text { AND } \\
\text { (surg* OR repair OR replacement) } \\
\text { AND } \\
\text { (cherry eye OR eyelid near/3 prolaps* OR third near/3 prolaps* OR }\end{array}$ \\
\hline
\end{tabular}




\begin{tabular}{|l|l|}
\hline & $\begin{array}{l}\text { nictita* near/3 prolaps* OR gland near/4 prolaps* OR gland near/4 } \\
\text { third OR gland near/4 eyelid OR gland near/4 nictita*) } \\
\text { AND } \\
\text { (pocket techni* OR tacking OR anchor* techni* or mucosa* near/3 } \\
\text { pocket OR anchor* near/4 orbital OR anchor* near/4 rim OR } \\
\text { imbricat*) }\end{array}$ \\
\hline Dates searches performed: & 24 April 2018 \\
\hline
\end{tabular}

\begin{tabular}{|c|c|}
\hline \multicolumn{2}{|l|}{ Exclusion / Inclusion Criteria } \\
\hline Exclusion: & $\begin{array}{l}\text { Only one technique performed (i.e. only anchoring OR mucosal } \\
\text { pocket) within the study group } \\
\text { Full article not available in English } \\
\text { Wrong species } \\
\text { Wrong disease } \\
\text { Book chapters }\end{array}$ \\
\hline Inclusion: & $\begin{array}{l}\text { Both anchoring and mucosal pocket techniques used amongst the } \\
\text { study group } \\
\text { Full text articles available in English } \\
\text { Dogs only }\end{array}$ \\
\hline
\end{tabular}

\begin{tabular}{|c|c|c|c|c|c|c|c|}
\hline \multicolumn{8}{|c|}{ Search Outcome } \\
\hline Database & $\begin{array}{c}\text { Number } \\
\text { of } \\
\text { results }\end{array}$ & $\begin{array}{l}\text { Excluded - } \\
\text { only one } \\
\text { technique } \\
\text { performed }\end{array}$ & $\begin{array}{l}\text { Excluded } \\
\text { - not in } \\
\text { English }\end{array}$ & $\begin{array}{c}\text { Excluded - } \\
\text { wrong } \\
\text { species }\end{array}$ & $\begin{array}{l}\text { Excluded - } \\
\text { not } \\
\text { relevant to } \\
\text { PICO } \\
\text { question }\end{array}$ & $\begin{array}{l}\text { Excluded } \\
\text { - book } \\
\text { chapters }\end{array}$ & $\begin{array}{c}\text { Total } \\
\text { relevant } \\
\text { papers }\end{array}$ \\
\hline $\begin{array}{l}\mathrm{CAB} \\
\text { Abstracts }\end{array}$ & 26 & 17 & 2 & 0 & 2 & 1 & 4 \\
\hline Medline & 6 & 3 & 0 & 1 & 1 & 0 & 1 \\
\hline $\begin{array}{l}\text { Web of } \\
\text { Science }\end{array}$ & 15 & 6 & 1 & 4 & 2 & 0 & 2 \\
\hline \multicolumn{7}{|c|}{ Total relevant papers when duplicates removed } & 4 \\
\hline
\end{tabular}


The authors declare no conflict of interest.

\section{REFERENCES}

1. Gökçe, A.P. (2001) Comparison of the Surgical Treatment Methods of Prolapsed Gland of the Third Eyelid in Dogs: A Retrospectif [sic] Study of 66 Cases (1995-2000). Veteriner Cerrahi Dergisi, 7 (1-2), 44-47 [Turkish, abstract in English].

2. Gross, S.L. (1983) Effectiveness of a Modification of the Blogg Technique for Replacing the Prolapsed Gland of the Canine Third Eyelid. Proceedings of the American College of Veterinary Ophthalmologists, $13,38-42$.

3. Gupta, A.K., Kushwaha, R.B., Bhadwal, M.S., Sharma, A., Dwivedi, D.K. \& Arafath, I. (2016) Management of Cherry Eye Using Different Surgical Techniques - A Study of 10 Dogs. Intas Polivet, 17 (11), 411-413.

4. Kaswan, R.L. \& Martin, C.L. (1985) Surgical Correction of Third Eyelid Prolapse in Dogs. Journal of the American Veterinary Medical Association, 186 (1), 83.

5. Lin, C.-T. \& Lin, N.-Y. (2003) Surgical Reposition of Third Eyelid Gland Prolapse (Cherry Eye) in the Dog. Taiwan Veterinary Journal, 29 (2), 85-89.

6. Morgan, R.V., Duddy, J.M. \& McClurg, K. (1993) Prolapse of the Gland of the Third Eyelid in Dogs: A Retrospective Study of 89 Cases (1980 to 1990). Journal of the American Animal Hospital Association, $29(1-2), 56-60$.

7. Multari, D., Perazzi, A., Contiero, B., De Mattia, G. \& lacopetti, I. (2016) Pocket Technique or Pocket Technique with Modified Orbital Rim Anchorage for the Replacement of a Prolapsed Gland of the Third Eyelid in Dogs: 353 Dogs. Veterinary Ophthalmology, 19 (3), 214-219. DOI: 1111/vop.12286

8. Stanley, R.G. \& Kaswan, R.L. (1994) Modification of the Orbital Rim Anchorage Method for Surgical Replacement of the Gland of the Third Eyelid in Dogs. Journal of the American Veterinary Medical Association, 205 (10), 1412-1414.

9. White, C. \& Brennan, M.L. (2018) An Evidence-Based Rapid Review of Surgical Techniques for Correction of Prolapsed Nictitans Glands in Dogs. Veterinary Sciences, 5 (75), 1-16.

DOI: $3390 /$ vetsci5030075 


\section{EVIIDEFeE

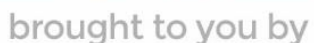 \\ RCVS KNOWLEDGE}

\section{Intellectual Property Rights}

Authors of Knowledge Summaries submitted to RCVS Knowledge for publication will retain copyright in their work, and will be required to grant RCVS Knowledge a non-exclusive license of the rights of copyright in the materials including but not limited to the right to publish, re-

publish, transmit, sell, distribute and otherwise use the materials in all languages and all media throughout the world, and to license or permit others to do so.

\section{Disclaimer}

Knowledge Summaries are a peer-reviewed article type which aims to answer a clinical question based on the best available current evidence. It does not override the responsibility

of the practitioner. Informed decisions should be made by considering such factors as individual clinical expertise and judgement along with patient's circumstances and owners' values. Knowledge Summaries are a resource to help inform and any opinions expressed within the Knowledge Summaries are the author's own and do not necessarily reflect the view of the RCVS Knowledge. Authors are responsible for the accuracy of the content. While the

Editor and Publisher believe that all content herein are in accord with current recommendations and practice at the time of publication, they accept no legal responsibility

for any errors or omissions, and make no warranty, express or implied, with respect to material contained within.

For further information please refer to our Terms of Use.

RCVS Knowledge is the independent charity associated with the Royal College of Veterinary Surgeons (RCVS). Our ambition is to become a global intermediary for evidence based veterinary knowledge by providing access to information

that is of immediate value to practicing veterinary professionals and directly contributes to evidence based clinical decision-making.

https://www.veterinaryevidence.org/

RCVS Knowledge is a registered Charity No. 230886.

Registered as a Company limited by guarantee in England and Wales No. 598443.

Registered Office: Belgravia House, 62-64 Horseferry Road, London SW1P 2AF

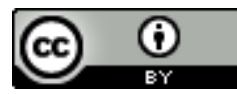

This work is licensed under a Creative Commons Attribution 4.0 International License 